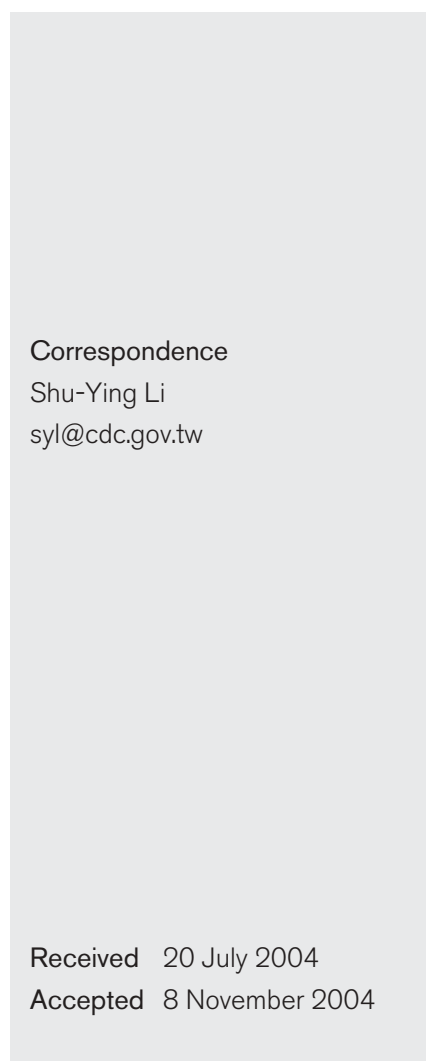

\title{
Comparison of four molecular typing methods to assess genetic relatedness of Candida albicans clinical isolates in Taiwan
}

\author{
Kuo-Wei Chen, ${ }^{1}$ Hsiu-Jung Lo, ${ }^{2}$ Yu-Hui Lin ${ }^{1}$ and Shu-Ying Li ${ }^{1}$ \\ ${ }^{1}$ Laboratory for Mycopathogens, Chlamydia and Mycoplasma, Division of Laboratory Research and \\ Development, Center for Disease Control, 161 Kun-Yang Street, Nan-Kang District, Taipei 115, \\ Taiwan \\ ${ }^{2}$ Division of Clinical Research, National Health Research Institutes, Taipei, Taiwan
}

\begin{abstract}
This report describes the investigation of the genetic profiles of 53 Candida albicans isolates collected from 18 hospitals in Taiwan using three PFGE-based typing methods (PFGE karyotyping, and PFGE of Sfil and BssHII restriction fragments) and one repetitive-sequence-PCR (rep-PCR) method. All four methods were able to identify clonal related isolates from the same patients. PFGE$B s s \mathrm{HIl}$ exhibited the highest discriminatory power by discriminating 40 genotypes, followed by PFGE-Sfil (35 genotypes) and then by rep-PCR (31 genotypes), while PFGE karyotyping exhibited the lowest discriminatory power (19 genotypes). High discriminatory power can also be achieved by combining typing methods with different typing mechanisms, such as rep-PCR and PFGE-based typing methods. The results also showed that the genotype of each isolate was patient-specific and not associated with the source of the isolation, geographic origin or antifungal resistance.
\end{abstract}

\section{INTRODUCTION}

In recent decades, the incidence of invasive Candida infections has increased and has emerged as an important public health problem (Hajjeh et al., 2004; Tortorano et al., 2003). Candida albicans accounts for more than $50 \%$ of systemic candidiasis and is the most pathogenic Candida species (Pfaller et al., 2000). Since 2001, Candida species and other yeasts have ranked as the third most frequent nosocomial infection in Taiwanese medical centres, with C. albicans being the leading cause of yeast infections (Chen et al., 2003).

Molecular typing methods are increasingly used in the analysis of strain relatedness in order to identify transmission routes (Elias Costa et al., 1999), decide on prophylaxis practices (Chen et al., 2001) and assess the biodiversity of a microbial population (Clemons et al., 1997). Molecular typing methods based on different principles have been developed to fulfil such purposes. These methods include RFLP of the whole genome by using EcoRI, HinfI and MspI restriction enzymes (Poikonen et al., 2001), RFLP followed by probe hybridization (Taylor et al., 2003), PFGE karyotyping, PFGE of fragments generated by rare-cutting restriction endonucleases such as SfiI (Kanellopoulou et al., 2001), SmaI, NotI and BssHII (Riederer et al., 1998), PCR finger-

Abbreviations: AFLP, amplified fragment length polymorphism; DI, discriminatory index; MLST, multi-locus sequence typing; RAPD, randomly amplified polymorphic DNA; rep-PCR, repetitive-sequence-PCR. printing of the whole genome by randomly amplified polymorphic DNA (RAPD) analysis (Samaranayake et al., 2003) or amplified fragment length polymorphism (AFLP) analysis (Ball et al., 2004), fingerprinting of repetitive sequences by repetitive-sequence-based PCR (rep-PCR; Redkar et al., 1996) and sequencing of house-keeping genes by multi-locus sequence typing (MLST; Bougnoux et al., 2003). Molecular typing methods should be reproducible, discriminatory, high throughput, easy-to-use, digitally portable and amenable to standardization and library typing (Soll, 2000). For more than two decades, PFGE-based typing methods have been widely used and shown to be discriminatory and reproducible. The method of rep-PCR represents a more convenient PCR-based genomic fingerprinting technique; it uses primers directed to the interspersed repetitive DNA elements present at certain characteristic locations in the genome. Rep-PCR has the advantage of being laboursaving, rapid and economical.

In this paper, we used three PFGE-based typing methods (PFGE karyotyping, SfiI-PFGE and BssHII-PFGE) and a repPCR typing method to study 53 clinical isolates of C. albicans collected from 18 hospitals in Taiwan. The aims of this study were to compare the discriminatory power of these four molecular typing methods and to ascertain whether different characteristics (e.g. drug resistance, geographic origin, source of isolate, nosocomial or not) could be attributed to certain specific molecular types in Taiwan. The most discriminatory typing method will be standardized and serve as 
the tool for future outbreak investigations and the basis for comparison of other typing methods. The data obtained in this study will also contribute to our attempt to establish a central genetic database of fungal pathogens and provide a platform for the comparison of domestic as well as international fungal genotypes.

\section{METHODS}

Fungal strains. A total of 53 C. albicans clinical isolates were used in this study. Information on each isolate was collected, including the MIC of fluconazole, geographic origin and body site origin, as well as whether it was a nosocomial infection. Nosocomial infections were identified by hospital infection control practitioners in the course of routine surveillance according to the criteria of the Center for Disease Control and Prevention (CDC) (Garner et al., 1988).

Forty-two isolates were part of the collections of the Taiwan Surveillance of Antimicrobial Resistance of Yeasts Project, which collected clinical strains isolated from 22 hospitals located in different geographic regions in Taiwan from 15 April to 15 June 1999 (Yang et al., 2004). Only one isolate was accepted during each episode of infection. The remaining 11 isolates (CDC-F003000393-CDC-F003000396, CDC-F003000399CDC-F003000402, CDC-F003000418-CDC-F003000420) were serial oral isolates collected from three HIV-infected patients between 2001 and 2002. The three HIV patients were outpatients from the same hospital.

The identification of all fungal strains was undertaken by the germ-tube assay followed by VITEK Yeast Biochemical Card and API-32C systems. The MICs for fluconazole of the C. albicans isolates were determined by the microdilution broth method according to the guidelines of the National Committee for Clinical Laboratory Standards (NCCLS) document M27-A, as described previously (Yang et al., 2003).

PFGE karyotyping. Strains were inoculated on Sabouraud dextrose agar (SDA; Difco) for $48 \mathrm{~h}$ at $37^{\circ} \mathrm{C}$. Colonies on agar were picked in a cell suspension buffer (100 mM Tris/HCl, $100 \mathrm{mM} \mathrm{EDTA,} \mathrm{pH} 8 \cdot 0)$. The cell density of the suspension for the plug was estimated by measuring the $\mathrm{OD}_{600}$ and adjusting to $\mathrm{OD}_{600} 1 \cdot 5$. The cells were pelleted by centrifugation at $3000 \mathrm{~g}$ for $5 \mathrm{~min}$ and resuspended in $500 \mu \mathrm{l}$ of cell suspension buffer. Then, $100 \mu \mathrm{l}$ of lyticase (Sigma; 1250 unit ml $^{-1}$ in $50 \%$ glycerol and $0 \cdot 01 \mathrm{M} \mathrm{N}_{3} \mathrm{PO}_{4}$ ) was added to the suspension, which was incubated at $37^{\circ} \mathrm{C}$ for $30 \mathrm{~min}$. Next, $600 \mu \mathrm{l}$ of $1 \%(\mathrm{w} / \mathrm{v})$ agarose (Seakem Gold agarose; BioWhittaker Molecular Applications) in TE buffer (10 mM Tris/HCl, $1 \mathrm{mM}$ EDTA, pH 8.0) was added. After mixing, the solution was poured into the wells of plug moulds and kept at room temperature for $5 \mathrm{~min}$ for solidification. The plugs were transferred into $50 \mathrm{ml}$ tubes containing $5 \mathrm{ml}$ of cell lysis buffer (100 mM Tris/HCl, pH 8•0, 0·45 M EDTA, pH 8·0, $1 \% \mathrm{~N}$-lauroylsarcosine, $1 \mathrm{mg}$ proteinase $\mathrm{K} \mathrm{ml}^{-1}$ ) and incubated overnight in a shaker water bath at $50{ }^{\circ} \mathrm{C}$. The plugs were washed twice with double-distilled $\mathrm{H}_{2} \mathrm{O}$ at $50{ }^{\circ} \mathrm{C}$ for $15 \mathrm{~min}$ and TE buffer at $50{ }^{\circ} \mathrm{C}$ for $10 \mathrm{~min}$ and then stored in TE buffer until use.

Electrophoresis was performed with a Biometra Rotaphor at pulse time $60-700 \mathrm{~s}$, angle $120^{\circ}, 120-90 \mathrm{~V}$ in $0.8 \%$ agarose gel with $0.5 \times \mathrm{TBE}$ ( $50 \mathrm{mM}$ Tris, $45 \mathrm{mM}$ boric acid, $0.5 \mathrm{mM}$ EDTA) for $66 \mathrm{~h}$. After electrophoresis, the gel was stained with ethidium bromide solution for $15 \mathrm{~min}$ and destained with distilled water. DNA fragments were imaged with IS-1000 Digital Imaging System (Alpha Innotech).

PFGE of Sfil and BssHII restriction fragments. The plugs were cut into 2-mm-wide slices. For Sfi I digestion, the slices were placed in $200 \mu \mathrm{l}$ of buffer 2 solution $\left(50 \mathrm{mM} \mathrm{NaCl}, 10 \mathrm{mM}\right.$ Tris/HCl, $10 \mathrm{mM} \mathrm{MgCl}_{2}$, $1 \mathrm{mM}$ DTT) containing $2 \mu \mathrm{l}$ of BSA (New England BioLabs) and incubated for $1 \mathrm{~h}$ at $50{ }^{\circ} \mathrm{C}$. The plug slices were transferred to $200 \mu \mathrm{l}$ of buffer 2 solution containing $2 \mu \mathrm{l}$ of BSA and 20 units of SfiI and incubated at $50{ }^{\circ} \mathrm{C}$ overnight. For Bss HII digestion, the slices were placed in $200 \mu \mathrm{l}$ of buffer 3 solution $(100 \mathrm{mM} \mathrm{NaCl}, 50 \mathrm{mM}$ Tris/ $\mathrm{HCl}$, $10 \mathrm{mM} \mathrm{MgCl}_{2}, 1 \mathrm{mM} \mathrm{DTT}$ ) (New England BioLabs) and incubated for $1 \mathrm{~h}$ at $50^{\circ} \mathrm{C}$. The plug slices were transferred to $200 \mu \mathrm{l}$ of buffer 3 solution containing 4 units of $\mathrm{Bss} \mathrm{HII}$ and incubated at $50{ }^{\circ} \mathrm{C}$ overnight. Electrophoresis was performed with a Biometra Rotaphor at pulse time $6-50 \mathrm{~s}$, angle $120^{\circ}, 180 \mathrm{~V}$ in $0.8 \%$ agarose gel with $0 \cdot 5 \times \mathrm{TBE}$ for $36 \mathrm{~h}$. After electrophoresis, the gel was stained with ethidium bromide solution for $15 \mathrm{~min}$ and destained with distilled water.

rep-PCR. The total genomic DNA of the strain was extracted by using PUREGENE DNA Purification Kit (Gentra) as was described previously (Hsu et al., 2003). The concentration of DNA extracted from C. albicans isolates was measured with a spectrophotometer $\left(A_{260}\right)$. DNA was stored at $-80^{\circ} \mathrm{C}$ until use.

The rep-PCR reaction was performed by using primers Ca-21 ( $5^{\prime}$ CATCTGTGGTGGAAAGTTAAC- $\left.3^{\prime}\right)$ and Ca-22 (5'-ATAATGCT CAAAGGTGGTAAG-3') designed from Care-2 repetitive elements and amplified variable regions between Care- 2 elements as described previously, with some modifications (Redkar et al., 1996). Reaction mixtures $(20 \mu \mathrm{l})$ consisted of $10 \mathrm{mM}$ Tris/ $\mathrm{HCl}(\mathrm{pH} 9 \cdot 0), 50 \mathrm{mM} \mathrm{KCl}$, $2.5 \mathrm{mM} \mathrm{MgCl}_{2}, 0 \cdot 1 \%$ Triton X-100, 0.2 mM dNTP mix, 50 pmol primer and 0.5 units of $\mathrm{Taq}$ polymerase. The amplification was performed by an initial denaturation at $95^{\circ} \mathrm{C}$ for 5 min followed by 40 cycles of denaturation at $94^{\circ} \mathrm{C}$ for $1 \mathrm{~min}$, annealing at $42^{\circ} \mathrm{C}$ for $1 \mathrm{~min}$ and extension at $72{ }^{\circ} \mathrm{C}$ for $2 \mathrm{~min}$, and a final extension at $72{ }^{\circ} \mathrm{C}$ for $5 \mathrm{~min}$ in a Tpersonal thermocycler (Biometra). PCR products were analysed by electrophoresis through $1.5 \%(\mathrm{w} / \mathrm{v})$ agarose gel (Seakem LE agarose; Cambrex) in 1× TBE buffer. Lambda ladder 100-3000 bp was used as a DNA size standard. Gel electrophoresis was conducted in TBE buffer at $100 \mathrm{~V} \mathrm{~cm}^{-1}$ for $50 \mathrm{~min}$. After electrophoresis, the gel was stained with ethidium bromide solution for $15 \mathrm{~min}$ and destained with distilled water.

Analysis of banding pattern. Dendrogram analysis was performed by using Bionumerics software version 3.0 (Applied Maths). Fingerprint similarity values were based on the presence or absence of bands between each profile pair being compared. The band inclusion window was adjusted by the size reference markers. Band assignment was done firstly by the automatic band search function of the software, then inspected visually to ensure that each assigned band had a characteristic densitometric profile of a Gaussian fit and had a corresponding band on the gel. Some weak bands resulting from incomplete digestion with restriction enzyme were excluded manually. Incomplete digestion of DNA was observed for some isolates; intermediate bands, resulting from incomplete cutting, were confirmed by repeating the digestion of the DNA with a different amount of enzyme. The position tolerance was set at $1 \%$ and optimization was set at $3 \%$. The Dice coefficient was used to analyse the similarities $\left(\mathrm{S}_{\mathrm{AB}}\right)$ of the band patterns. The unweighted pair group method using arithmetic averages (UPGMA) was used for cluster analysis. Isolates were considered different when the band similarity value was less than $95 \%$ (Voss et al., 1998).

Calculation of discriminatory power. The discriminatory index (DI) of each of the four typing methods was determined by the application of Simpson's index (Hunter \& Fraser, 1989). The DI is a measure of the probability that two unrelated strains sampled from the test population will be placed into different typing groups. A DI value of 1.0 would indicate that a typing method was able to distinguish each member of a strain population from all other members of that population. Conversely, a DI of $0 \cdot 0$ would indicate that all members of a strain population were of an identical type. 


\section{RESULTS AND DISCUSSION}

The increasing frequency of invasive fungal infections and the high mortality rate associated with disseminated fungal diseases have underscored the importance of understanding the molecular epidemiology of fungal infections. We compared four molecular typing methods to ascertain their potential for outbreak investigation and to see whether different characteristics (drug resistance, geographic origin, source of isolation, nosocomial or not) could be attributed to certain specific molecular types in Taiwan. The data obtained in this study will serve as a tool for future outbreak investigations and a basis for comparison basis for other typing methods.

In this study, genetic profiles of 53 C. albicans clinical isolates from 45 patients were obtained and compared by PFGE karyotyping (Fig. 1), PFGE of Sfi I (Fig. 2) and BssHII (Fig. 3) restriction fragments, and rep-PCR analysis (Fig. 4). All isolates were typable by all four typing methods. PFGE$B s s \mathrm{HII}$ and -Sfi generated $40(\mathrm{DI}=0.995)$ and 35 $(\mathrm{DI}=0.985)$ DNA patterns, respectively, for the 53 isolates, and were the most discriminatory in distinguishing isolates. Within the 42 isolates collected from different hospitals, 38 genotypes were found by using the PFGE-BssHII method. The rep-PCR method revealed 31 distinct genotypes $(\mathrm{DI}=0 \cdot 983)$. PFGE karyotyping displayed seven- and eight-band patterns (excluding $\mathrm{R}$ chromosome) and was the least discriminatory method, generating 19 karyotypes $(\mathrm{DI}=0.929)$ among the 53 strains analysed. When the $\mathrm{R}$ chromosome was considered in PFGE karyotyping, more patterns (25 types) were yielded (data not shown). However, the frequent size variation of $\mathrm{R}$ chromosome mainly stems from rRNA gene copy number differences and can alter within one cell division (Wickes et al., 1991). Therefore, the dendrogram was constructed without analysing the $\mathrm{R}$ chromosome.

In contrast to the 42 isolates collected from different episodes, the year-long recurrent isolates from HIV patients served here as clonal/epidemiologically related isolates. All four methods were able to identify clonal related isolates from the same patients. Isolates from the same HIV patient belonged to one unique genotype. The 11 isolates collected from three HIV patients were assigned to three molecular types by all four typing methods. PFGE-restriction fragment methods yielded better results but the restriction endonuclease may vary by strains or species.

Ideally, a fingerprint pattern should comprise 20-30 bands within a wider molecular range. Restriction with the endonuclease NotI (Diaz-Guerra et al., 1997) or SmaI (Doi et al., 1994) generated around 10 bands in narrower molecular ranges, which was not sufficient. PFGE-SfiI and -BssHII, which recognize 13 and 6 bp restriction sites, respectively, provided more resolving power for the molecular typing of C. albicans infections. Restriction with the endonuclease $S f i \mathrm{I}$ generated 18-22 (mean, 20) clear and well-separated fragments in the range of $40-1100 \mathrm{~kb}$, which allowed clear differentiation with reasonable discriminatory power. PFGE-
Bss HII resulted in more banding patterns (mean, 31 fragments; range $50-1000 \mathrm{~kb}$ ) and provided the highest discriminatory power. Nevertheless, scoring PFGE-BssHII banding patterns was more time-consuming than PFGE-SfiI. An alternative would be to use $S f i$ as the first typing enzyme, with the indistinguishable strains further typed by BssHII. A combination of PFGE-SfiI and -BssHII methods resulted in a DI of $1 \cdot 0$.

For PFGE-based methods, band differences in DNA fingerprint profiles are primarily a result of polymorphisms in the recognition sites of individual restriction enzymes, translocation (Iwaguchi et al., 2000) or reorganization of nonrDNA-containing chromosomes, or the non-reciprocal reorganization of rRNA gene cistrons in the rRNAgene-containing chromosomes (Ramsey et al., 1994). High concordance was found among the three PFGE-based methods (Table 1).

To our knowledge, no previous report has compared PFGEbased typing methods with the rep-PCR method for delineation of fungal strains. The PCR-based methods are less labour-intensive, and thus, potentially more suitable for routine use. A problem with RAPD typing using short and non-specific primers under low-stringency conditions is a lack of reproducibility (Dassanayake \& Samaranayake, 2003). rep-PCR is chosen because it is based on an alternative typing mechanism, i.e. inter-repetitive sequence length polymorphism analysis, and is very simple and reproducible. Our data showed that PCR amplification of repetitive DNA elements in the Candida genome using the Ca-21 and Ca-22 primer pair generated simple patterns and offered less clustering and discriminatory power than PFGE with restriction enzymes. Low concordance was found between rep-PCR and the three PFGE-based methods (Table 1). However, when rep-PCR was used as a secondary typing method supplementary to electrokaryotyping, PFGE-Sfi I or PFGEBssHII typing methods, high discriminatory indices of 0.996, 0.998 and 0.998 , respectively, were obtained. The results highlight the usefulness of a combination of typing methods with different typing mechanisms.

All four methods used in this study were reproducible. This was demonstrated by the same DNA pattern being obtained in consecutive isolates from the same HIV patient and obtaining the same results by different experiments and in repeated runs.

Choosing appropriate molecular typing methods is essential for identifying the clonal relatedness of pathogens. The data obtained in this study will help to establish benchmarks for future surveillance in Taiwan, which will also serve as a basis for comparison of other typing methods.

Our results showed that the genotype of each isolate was patient-specific and no specific genotypes were predominant as to their ability to cause nosocomial infection or bloodstream infections. The panel of isolates used in this study were collected from 18 hospitals located around Taiwan and thus gave a good representation of diverse geographic origin. The 


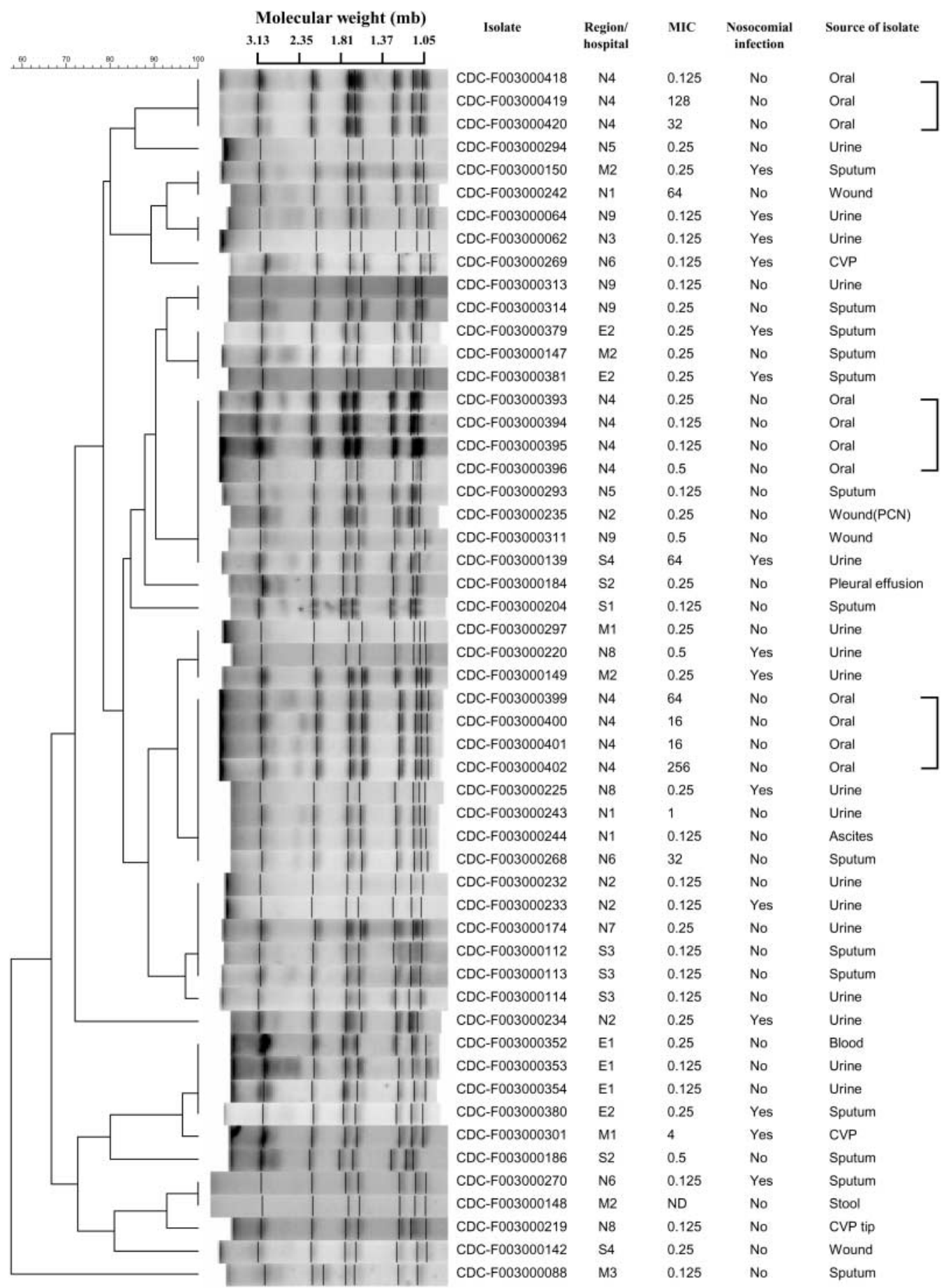

Fig. 1. Cluster analysis of the $53 \mathrm{C}$. albicans isolates based on the pattern of electrophoresis karyotype. Each of the three HIV patients was marked by a frame. Regions: N, north; S, south; M, middle; E, east. MIC indicates the MIC of fluconazole of each of the isolates. ND, Not determined.

extensive dispersion of genotypes among different hospitals illustrated that no correlation between genotypes and hospital/geographic origin could be established.

Monitoring genotype variations could have great implica- tions for antifungal regimens. The five fluconazole-resistant strains (MIC $>64 \mu \mathrm{g} \mathrm{ml}^{-1}$ ) were not clustered by any of the four typing methods (as shown in Figs 1, 2, 3 and 4) and the year-long recurrent isolates from each of the three HIV patients exhibited fluctuating fluconazole susceptibility/re- 


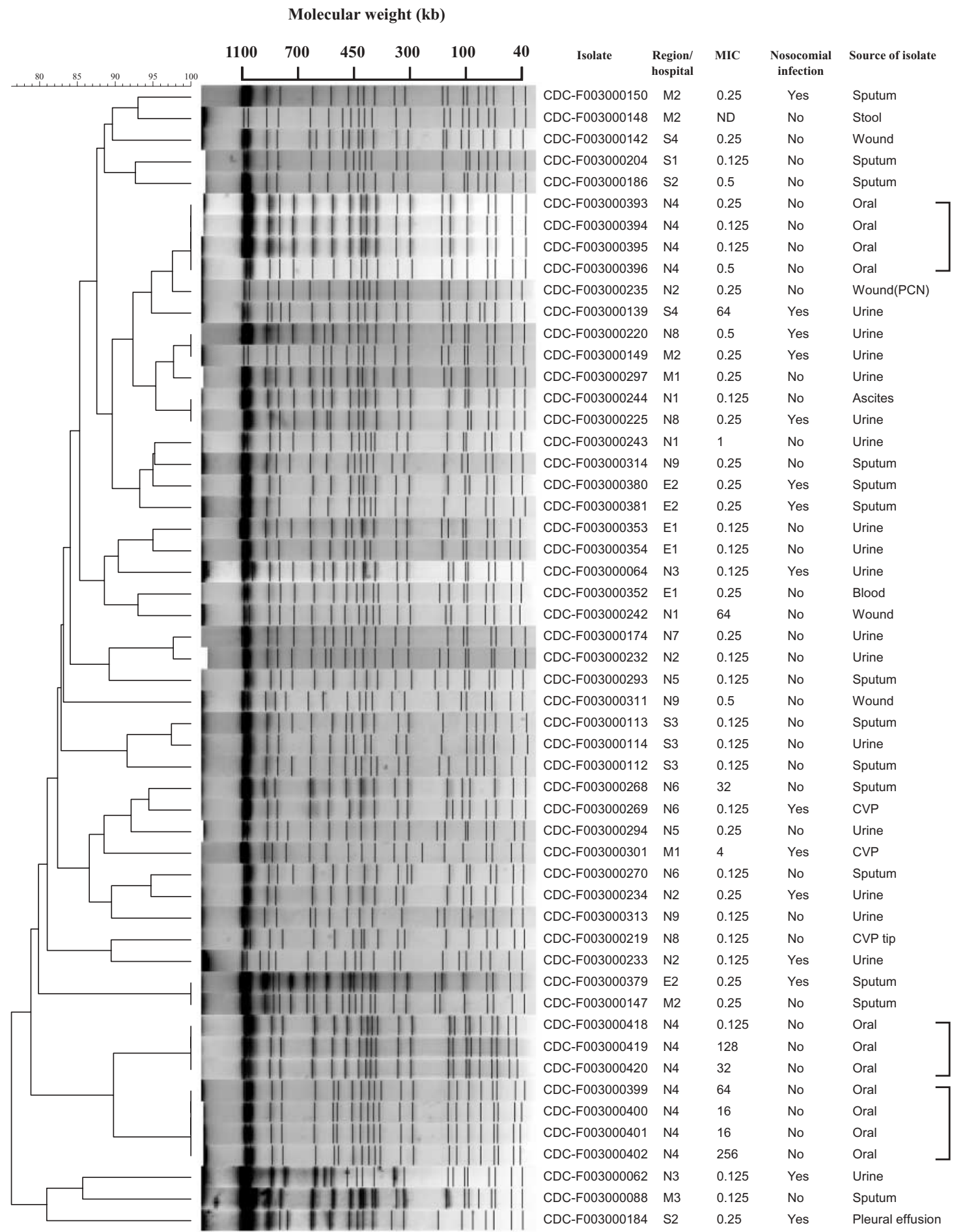

Fig. 2. Cluster analysis of the $53 \mathrm{C}$. albicans isolates based on the pattern of Sfil restriction endonuclease analysis of genomic DNA. Each of the three HIV patients was marked by a frame. Regions: N, north; S, south; M, middle; E, east. MIC indicates the MIC of fluconazole of each of the isolates. ND, Not determined.

sistance levels but maintained the same genotype (Table 1). The scenario in our study is in concordance with many previous reports employing $\mathrm{Ca} 3$ repetitive element hybridization or RAPD methods (Dassanayake et al., 2002; Lasker et al.,2001; Makarova et al., 2003). The difference in resistance to fluconazole is associated with subtle changes of genes involved in azole resistance (Franz et al., 1998). For the detection of mutation, deletion or insertion events associated with drug 


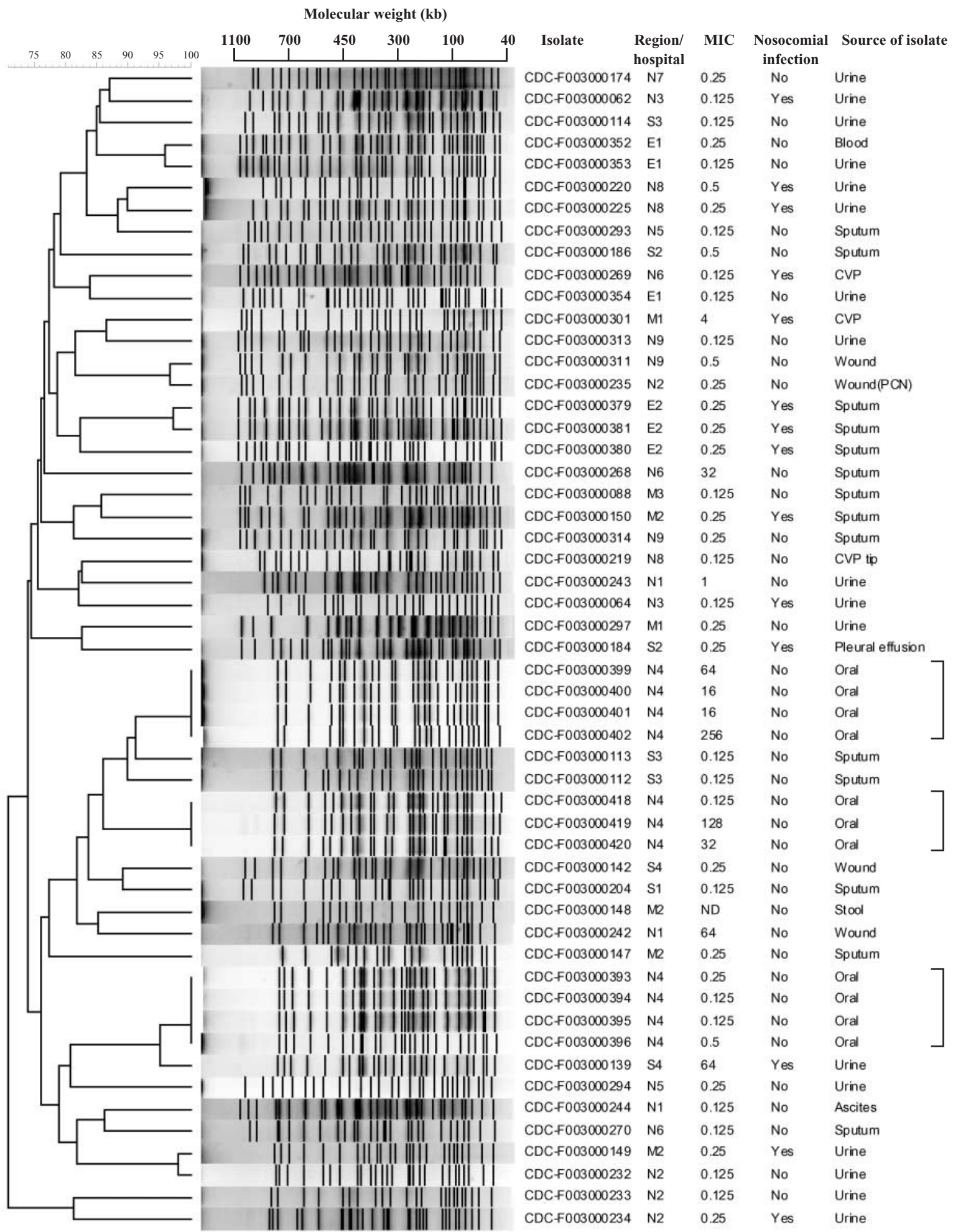

Fig. 3. Cluster analysis of the $53 \mathrm{C}$. albicans isolates based on the pattern of BssHII restriction endonuclease analysis of genomic DNA. Each of the three HIV patients was marked by a frame. Regions: N, north; S, south; M, middle; E, east. MIC indicates the MIC of fluconazole of each of the isolates. ND, Not determined. 


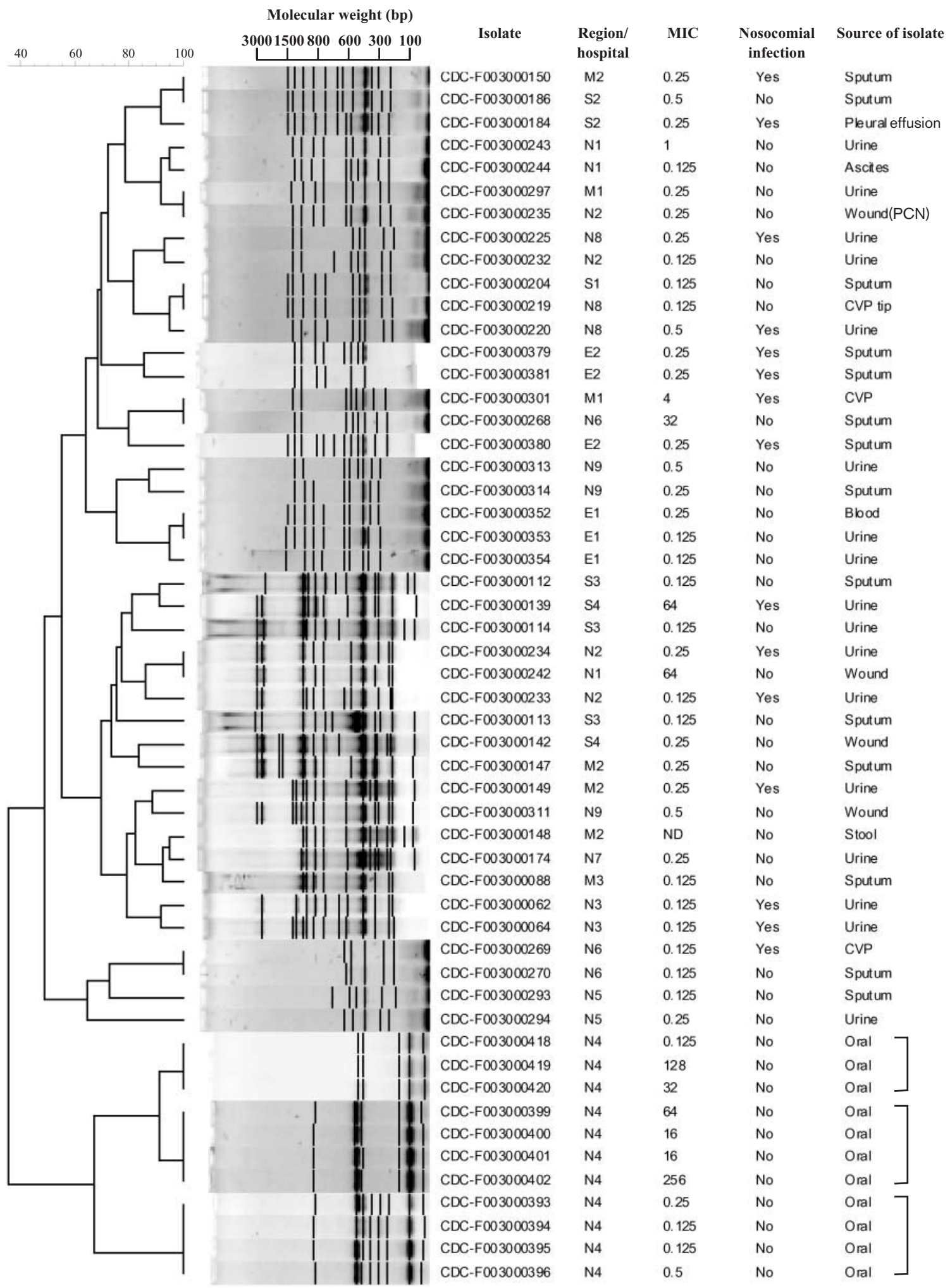

Fig. 4. Cluster analysis of the $53 \mathrm{C}$. albicans isolates based on the pattern of rep-PCR. Each of the three HIV patients was marked by a frame. Regions: N, north; S, south; M, middle; E, east. MIC indicates the MIC of fluconazole of each of the isolates. ND, Not determined. 
Table 1. Genotypes of 53 isolates of C. albicans

\begin{tabular}{|c|c|c|c|c|c|c|c|c|c|}
\hline Code no. & $\begin{array}{c}\text { PFGE karyotype } \\
\text { (excluding R } \\
\text { chromosome) }\end{array}$ & $\begin{array}{c}\text { PFGE } \\
\text { SfiI }\end{array}$ & $\begin{array}{l}\text { PFGE } \\
\text { BssHII }\end{array}$ & $\begin{array}{l}\text { Rep } \\
\text { PCR }\end{array}$ & $\begin{array}{l}\text { Source of } \\
\text { isolation }\end{array}$ & $\begin{array}{l}\text { Geological origin } \\
(\text { region } \dagger / \text { hospital })\end{array}$ & $\begin{array}{l}\text { Fluconazole MIC } \\
\qquad\left(\mu \mathrm{g} \mathrm{ml}^{-1}\right)\end{array}$ & $\begin{array}{l}\text { Nosocomial } \\
\text { infection }\end{array}$ & $\begin{array}{l}\text { HIV } \\
\text { status }\end{array}$ \\
\hline CDC F003000062 & $\mathrm{A} 1$ & B1 & $\mathrm{C} 1$ & D1 & Urine & N3 & $0 \cdot 125$ & Yes & - \\
\hline CDC F003000064 & Al & B2 & $\mathrm{C} 2$ & D1 & Urine & N3 & $0 \cdot 125$ & Yes & - \\
\hline CDC F003000088 & $\mathrm{A} 2$ & B3 & $\mathrm{C} 3$ & D2 & Sputum & M3 & $0 \cdot 125$ & No & - \\
\hline CDC F003000112 & $\mathrm{A} 3$ & B4 & $\mathrm{C} 4$ & D3 & Sputum & S3 & $0 \cdot 125$ & No & - \\
\hline CDC F003000113 & $\mathrm{A} 3$ & B5 & $\mathrm{C} 5$ & $\mathrm{D} 4$ & Sputum & S3 & $0 \cdot 125$ & No & - \\
\hline CDC F003000114 & $\mathrm{A} 3$ & B5 & C6 & D5 & Urine & S3 & $0 \cdot 125$ & No & - \\
\hline CDC F003000139 & $\mathrm{A} 4$ & B6 & $\mathrm{C} 7$ & D6 & Urine & S4 & 64 & Yes & - \\
\hline CDC F003000142 & A5 & B7 & $\mathrm{C} 8$ & D7 & Wound & S4 & $0 \cdot 25$ & No & - \\
\hline CDC F003000147 & A6 & B8 & $\mathrm{C} 9$ & D8 & Sputum & M2 & $0 \cdot 25$ & No & - \\
\hline CDC F003000148 & A7 & B9 & $\mathrm{C} 10$ & $\mathrm{D} 2$ & Stool & M2 & ND & No & - \\
\hline CDC F003000149 & A8 & $\mathrm{B} 10$ & $\mathrm{C} 11$ & D9 & Urine & M2 & $0 \cdot 25$ & Yes & - \\
\hline CDC F003000150 & A9 & B11 & $\mathrm{C} 12$ & $\mathrm{D} 10$ & Sputum & M2 & $0 \cdot 25$ & Yes & - \\
\hline CDC F003000174 & A3 & B12 & $\mathrm{C} 13$ & D2 & Urine & N7 & $0 \cdot 25$ & No & - \\
\hline CDC F003000184 & $\mathrm{A} 10$ & B13 & $\mathrm{C} 14$ & D11 & Pleural effusion & S2 & $0 \cdot 25$ & Yes & - \\
\hline CDC F003000186 & A11 & B14 & $\mathrm{C} 15$ & D10 & Sputum & S2 & $0 \cdot 5$ & No & - \\
\hline CDC F003000204 & $\mathrm{A} 12$ & B15 & $\mathrm{C} 16$ & D12 & Sputum & S1 & $0 \cdot 125$ & No & - \\
\hline CDC F003000219 & $\mathrm{A} 13$ & B16 & $\mathrm{C} 17$ & $\mathrm{D} 12$ & CVP & N8 & $0 \cdot 125$ & No & - \\
\hline CDC F003000220 & A8 & $\mathrm{B} 10$ & $\mathrm{C} 18$ & D12 & Urine & N8 & $0 \cdot 5$ & Yes & - \\
\hline CDC F003000225 & A8 & $\mathrm{B} 10$ & $\mathrm{C} 19$ & D13 & Urine & N8 & $0 \cdot 25$ & Yes & - \\
\hline CDC F003000232 & A3 & B12 & $\mathrm{C} 20$ & D13 & Urine & $\mathrm{N} 2$ & $0 \cdot 125$ & No & - \\
\hline CDC F003000233 & A3 & B17 & $\mathrm{C} 21$ & D14 & Urine & $\mathrm{N} 2$ & $0 \cdot 125$ & Yes & - \\
\hline CDC F003000234 & A14 & B18 & $\mathrm{C} 22$ & D15 & Urine & N2 & $0 \cdot 25$ & Yes & - \\
\hline CDC F003000235 & $\mathrm{A} 4$ & B6 & $\mathrm{C} 23$ & D16 & Wound (PCN) & $\mathrm{N} 2$ & $0 \cdot 25$ & No & - \\
\hline CDC F003000242 & A9 & B19 & $\mathrm{C} 24$ & D15 & Wound & N1 & 64 & No & - \\
\hline CDC F003000243 & A8 & B20 & $\mathrm{C} 11$ & D17 & Urine & N1 & 1 & No & - \\
\hline CDC F003000244 & A8 & $\mathrm{B} 10$ & $\mathrm{C} 25$ & D17 & Ascites & $\mathrm{N} 1$ & $0 \cdot 125$ & No & - \\
\hline CDC F003000268 & A8 & B21 & $\mathrm{C} 26$ & D18 & Sputum & N6 & 32 & No & - \\
\hline CDC F003000269 & A15 & B22 & $\mathrm{C} 27$ & D19 & CVP & N6 & $0 \cdot 125$ & Yes & - \\
\hline CDC F003000270 & A7 & B23 & $\mathrm{C} 28$ & D19 & Sputum & N6 & $0 \cdot 125$ & No & - \\
\hline CDC F003000293 & A4 & B24 & $\mathrm{C} 29$ & D20 & Sputum & N5 & $0 \cdot 125$ & No & - \\
\hline CDC F003000294 & A16 & B25 & $\mathrm{C} 30$ & D21 & Urine & N5 & $0 \cdot 25$ & No & - \\
\hline CDC F003000297 & A8 & $\mathrm{B} 10$ & C31 & D16 & Urine & M1 & $0 \cdot 25$ & No & - \\
\hline CDC F003000301 & $\mathrm{A} 17$ & B26 & $\mathrm{C} 32$ & D18 & CVP & M1 & 4 & Yes & - \\
\hline CDC F003000311 & $\mathrm{A} 4$ & B27 & $\mathrm{C} 22$ & D22 & Wound & N9 & $0 \cdot 5$ & No & - \\
\hline CDC F003000313 & A18 & B28 & $\mathrm{C} 33$ & D23 & Urine & N9 & $0 \cdot 125$ & No & - \\
\hline CDC F003000314 & A18 & B29 & $\mathrm{C} 34$ & D24 & Sputum & N9 & $0 \cdot 25$ & No & - \\
\hline CDC F003000352 & $\mathrm{A} 17$ & $\mathrm{~B} 30$ & C35 & D25 & Blood & E1 & $0 \cdot 25$ & No & - \\
\hline CDC F003000353 & $\mathrm{A} 17$ & B31 & C35 & D25 & Urine & E1 & $0 \cdot 125$ & No & - \\
\hline CDC F003000354 & A17 & B31 & C36 & D25 & Urine & E1 & $0 \cdot 125$ & No & - \\
\hline CDC F003000379 & A6 & B8 & $\mathrm{C} 37$ & D26 & Sputum & E2 & $0 \cdot 25$ & Yes & - \\
\hline CDC F003000380 & $\mathrm{A} 17$ & B32 & $\mathrm{C} 38$ & D27 & Sputum & E2 & $0 \cdot 25$ & Yes & - \\
\hline CDC F003000381 & A6 & B33 & $\mathrm{C} 37$ & D28 & Sputum & E2 & $0 \cdot 25$ & Yes & - \\
\hline CDC F003000393 & A4 & B6 & $\mathrm{C} 7$ & D29 & Oral & $\mathrm{N} 4$ & $0 \cdot 25$ & No & + \\
\hline CDC F003000394 & A4 & B6 & $\mathrm{C} 7$ & D29 & Oral & N4 & $0 \cdot 125$ & No & + \\
\hline CDC F003000395 & A4 & B6 & $\mathrm{C} 7$ & D29 & Oral & $\mathrm{N} 4$ & $0 \cdot 125$ & No & + \\
\hline CDC F003000396 & A4 & B6 & $\mathrm{C} 7$ & D29 & Oral & $\mathrm{N} 4$ & $0 \cdot 5$ & No & + \\
\hline CDC F003000399 & A8 & B34 & C39 & D30 & Oral & $\mathrm{N} 4$ & 64 & No & + \\
\hline CDC F003000400 & A8 & B34 & C39 & D30 & Oral & $\mathrm{N} 4$ & 16 & No & + \\
\hline CDC F003000401 & A8 & B34 & C39 & D30 & Oral & N4 & 16 & No & + \\
\hline CDC F003000402 & A8 & B34 & C39 & D30 & Oral & $\mathrm{N} 4$ & 256 & No & + \\
\hline CDC F003000418 & A19 & B35 & $\mathrm{C} 40$ & D31 & Oral & $\mathrm{N} 4$ & $0 \cdot 125$ & No & + \\
\hline
\end{tabular}


Table 1. cont.

\begin{tabular}{|c|c|c|c|c|c|c|c|c|c|}
\hline Code no. & $\begin{array}{l}\text { PFGE karyotype } \\
\text { (excluding R } \\
\text { chromosome) }\end{array}$ & $\begin{array}{l}\text { PFGE } \\
\text { SfiI }\end{array}$ & $\begin{array}{l}\text { PFGE } \\
\text { BssHII }\end{array}$ & $\begin{array}{l}\text { Rep } \\
\text { PCR }\end{array}$ & $\begin{array}{l}\text { Source of } \\
\text { isolation }^{\star}\end{array}$ & $\begin{array}{l}\text { Geological origin } \\
\text { (region } \dagger / \text { hospital) }\end{array}$ & $\begin{array}{l}\text { Fluconazol MIC } \\
\qquad\left(\mu \mathrm{g} \mathrm{ml}^{-1}\right)\end{array}$ & $\begin{array}{l}\text { Nosocomial } \\
\text { infection }\end{array}$ & $\begin{array}{l}\text { HIV } \\
\text { status }\end{array}$ \\
\hline CDC F003000419 & A19 & B35 & $\mathrm{C} 40$ & D31 & Oral & $\mathrm{N} 4$ & 128 & No & + \\
\hline CDC F003000420 & A19 & B35 & $\mathrm{C} 40$ & D31 & Oral & N4 & 32 & No & + \\
\hline
\end{tabular}

ND, Not determined.

${ }^{*} \mathrm{CVP}$, central venous pressure line; PCN, percutaneous nephrostomy.

$\dagger \mathrm{N}$, north; S, south; $\mathrm{M}$, middle; $\mathrm{E}$, east.

resistance, DNA sequencing may be more suitable than the genome fingerprinting methods used in this study (Lee et al., 2004). Methods based on the C. albicans nucleotide sequence (such as the MLST) as a robust characterization system and the possibility of storing data in a central database (http:// calbicans.mlst.net) have been proposed. This greatly facilitates standardization and international data exchange of molecular typing information via the internet for global epidemiology (Dodgson et al., 2003; Robles et al., 2004; Tavanti etal., 2004). The results from PFGE-RFLP approaches are often laboratory-dependent; however, with standardized protocols, inter-laboratory comparison of data is still feasible. Before sequence-based typing methods such as MLST gain global consensus and popularity, the highly discriminatory PFGE-RFLP approaches demonstrated here still remain useful and cost-effective tools in outbreak investigation.

\section{ACKNOWLEDGEMENTS}

This work was in part supported by grants DOH92-DC-2012 and DOH93-DC-2014 from the Center for Disease Control, Department of Health, Taiwan.

We are grateful to Dr Chien-Shun Chiou for constructive comments and discussion. We would like to express our sincere appreciation to all 18 participating hospitals for providing the strains and information related to these strains. They are Chang Gung Memorial Hospital at Linkou, Chang Gung Memorial Hospital at Keelung, Hsin-Chu Hospital, Lo-Tung Poh Ai Hospital, Lo-Tung St Mary Hospital, National Taiwan University Hospital, Taiwan Adventist Hospital, Koo Foundation Sun Yat-sen cancer center, Tri Service General Hospital, Kuan-Tien General Hospital, Veterans General HospitalTaichung, Zen Ai General Hospital, Chi Mei Hospital, Kaohsiung Medical College Chung-Ho Memorial Hospital, Kaohsiung Military Hospital, Veterans General Hospital-Kaohsiung, Buddhist Tzu-Chi General Hospital in Hua-Lien and Mackay Memorial Hospital Taitung Branch.

\section{REFERENCES}

Ball, L. M., Bes, M. A., Theelen, B., Boekhout, T., Egeler, R. M. \& Kuijper, E. J. (2004). Significance of amplified fragment length polymorphism in identification and epidemiological examination of Candida species colonization in children undergoing allogeneic stem cell transplantation. J Clin Microbiol 42, 1673-1679.

Bougnoux, M. E., Tavanti, A., Bouchier, C., Gow, N. A., Magnier, A.,
Davidson, A. D., Maiden, M. C., D'Enfert, C. \& Odds, F. C. (2003). Collaborative consensus for optimized multilocus sequence typing of Candida albicans. J Clin Microbiol 41, 5265-5266.

Chen, Y. C., Chang, S. C., Tai, H. M., Hsueh, P. R. \& Luh, K. T. (2001). Molecular epidemiology of Candida colonizing critically ill patients in intensive care units. J Formos Med Assoc 100, 791-797.

Chen, Y. C., Chang, S. C., Luh, K. T. \& Hsieh, W. C. (2003). Stable susceptibility of Candida blood isolates to fluconazole despite increasing use during the past 10 years. J Antimicrob Chemother 52, 71-77.

Clemons, K. V., Feroze, F., Holmberg, K. \& Stevens, D. A. (1997). Comparative analysis of genetic variability among Candida albicans isolates from different geographic locales by three genotypic methods. J Clin Microbiol 35, 1332-1336.

Dassanayake, R. S. \& Samaranayake, L. P. (2003). Amplificationbased nucleic acid scanning techniques to assess genetic polymorphism in Candida. Crit Rev Microbiol 29, 1-24.

Dassanayake, R. S., Ellepola, A. N., Samaranayake, Y. H. \& Samaranayak, L. P. (2002). Molecular heterogeneity of fluconazole-resistant and -susceptible oral Candida albicans isolates within a single geographic locale. APMIS 110, 315-324.

Diaz-Guerra, T. M., Martinez-Suarez, J. V., Laguna, F. \& RodriguezTudela, J. L. (1997). Comparison of four molecular typing methods for evaluating genetic diversity among Candida albicans isolates from human immunodeficiency virus-positive patients with oral candidiasis. J Clin Microbiol 35, 856-861.

Dodgson, A. R., Pujol, C., Denning, D. W., Soll, D. R. \& Fox, A. J. (2003). Multilocus sequence typing of Candida glabrata reveals geographically enriched clades. J Clin Microbiol 41, 5709-5717.

Doi, M., Mizuguchi, I., Homma, M. \& Tanaka, K. (1994). Electrophoretic karyotypes of Candida yeasts recurrently isolated from single patients. Microbiol Immunol 38, 19-23.

Elias Costa, M. R., Carnovale, S. \& Relloso, M. S. (1999). Oropharyngeal candidosis in AIDS patients: an epidemiological study using restriction analysis of Candida albicans total genomic DNA. Mycoses 42, $41-46$.

Franz, R., Kelly, S. L., Lamb, D. C., Kelly, D. E., Ruhnke, M. \& Morschhauser, J. (1998). Multiple molecular mechanisms contribute to a stepwise development of fluconazole resistance in clinical Candida albicans strains. Antimicrob Agents Chemother 42, 3065-3072.

Garner, J. S., Jarvis, W. R., Emori, T. G., Horan, T. C. \& Hughes, J. M. (1988). CDC definitions for nosocomial infections. Am J Infect Control $16,128-140$.

Hajjeh, R. A., Sofair, A. N., Harrison, L. H. \& 13 other authors (2004). Incidence of bloodstream infections due to Candida species and in vitro susceptibilities of isolates collected from 1998 to 2000 in a populationbased active surveillance program. J Clin Microbiol 42, 1519-1527. 
Hsu, M. C., Chen, K. W., Lo, H. J., Chen, Y. C., Liao, M. H., Lin, Y. H. \& Li, S. Y. (2003). Species identification of medically important fungi by use of real-time LightCycler PCR. J Med Microbiol 52, 1071-1076.

Hunter, P. R. \& Fraser, C. A. (1989). Application of a numerical index of discriminatory power to a comparison of four physiochemical typing methods for Candida albicans. J Clin Microbiol 27, 2156-2160.

Iwaguchi, S. I., Kanbe, T., Tohne, T., Magee, P. T. \& Suzuki, T. (2000). High-frequency occurrence of chromosome translocation in a mutant strain of Candida albicans by a suppressor mutation of ploidy shift. Yeast 16, 411-422.

Kanellopoulou, M., Stamos, G., Petinnelli, I., Savala, M., Tzimogianni, A., Legakis, N. J., Foustoukou, M., Papafragas, E. \& Velegraki, A. (2001). Subtyping and antifungal susceptibilities of Candida spp. in the intensive care unit of a Greek general hospital. Int J Antimicrob Agents 18, 179-183.

Lasker, B. A., Elie, C. M., Lott, T. J. \& 9 other authors (2001). Molecular epidemiology of Candida albicans strains isolated from the oropharynx of HIV-positive patients at successive clinic visits. Med Mycol 39, 341352

Lee, M. K., Williams, L. E., Warnock, D. W. \& Arthington-Skaggs, B. A. (2004). Drug resistance genes and trailing growth in Candida albicans isolates. J Antimicrob Chemother 53, 217-224.

Makarova, N. U., Pokrowsky, V. V., Kravchenko, A. V., Serebrovskaya, L. V., James, M. J., McNeil, M. M., Lasker, B. A., Warnock, D. W. \& Reiss, E. (2003). Persistence of oropharyngeal Candida albicans strains with reduced susceptibilities to fluconazole among human immunodeficiency virus-seropositive children and adults in a long-term care facility. J Clin Microbiol 41, 1833-1837.

Pfaller, M. A., Jones, R. N., Doern, G. V., Sader, H. S., Messer, S. A Houston, A., Coffman, S. \& Hollis, R. J. (2000). Bloodstream infections due to Candida species: SENTRY antimicrobial surveillance program in North America and Latin America, 1997-1998. Antimicrob Agents Chemother 44, 747-751.

Poikonen, E., Vuopio-Varkila, J., Kaukoranta-Tolvanen, S. S., Sivonen, A., Siren, E. \& Ruutu, P. (2001). Epidemiological typing of Candida albicans from bloodstream infections by restriction enzyme analysis. Scand J Infect Dis 33, 140-144.

Ramsey, H., Morrow, B. \& Soll, D. R. (1994). An increase in switching frequency correlates with an increase in recombination of the ribosomal chromosomes of Candida albicans strain 3153A. Microbiology 140, $1525-1531$.

Redkar, R. J., Dube, M. P., McCleskey, F. K., Rinaldi, M. G. \& Del Vecchio, V. G. (1996). DNA fingerprinting of Candida rugosa via repetitive sequence-based PCR. J Clin Microbiol 34, 1677-1681.
Riederer, K., Fozo, P. \& Khatib, R. (1998). Typing of Candida albicans and Candida parapsilosis: species-related limitations of electrophoretic karyotyping and restriction endonuclease analysis of genomic DNA. Mycoses 41, 397-402.

Robles, J. C., Koreen, L., Park, S. \& Perlin, D. S. (2004). Multilocus sequence typing is a reliable alternative method to DNA fingerprinting for discriminating among strains of Candida albicans. J Clin Microbiol 42, 2480-2488

Samaranayake, Y. H., Samaranayake, L. P., Dassanayake, R. S., Yau, J. Y., Tsang, W. K., Cheung, B. P. \& Yeung, K. W. (2003). 'Genotypic shuffling' of sequential clones of Candida albicans in HIV-infected individuals with and without symptomatic oral candidiasis. $J$ Med Microbiol 52, 349-359.

Soll, D. R. (2000). The ins and outs of DNA fingerprinting the infectious fungi. Clin Microbiol Rev 13, 332-370.

Tavanti, A., Gow, N. A., Maiden, M. C., Odds, F. C. \& Shaw, D. J. (2004). Genetic evidence for recombination in Candida albicans based on haplotype analysis. Fungal Genet Biol 41, 553-562.

Taylor, B. N., Harrer, T., Pscheidl, E., Schweizer, A., Rollinghoff, M. \& Schroppel, K. (2003). Surveillance of nosocomial transmission of Candida albicans in an intensive care unit by DNA fingerprinting. J Hosp Infect 55, 283-289.

Tortorano, A. M., Rigoni, A. L., Biraghi, E., Prigitano, A. \& Viviani, M. A (2003). The European Confederation of Medical Mycology (ECMM) survey of candidaemia in Italy: antifungal susceptibility patterns of 261 non-albicans Candida isolates from blood. J Antimicrob Chemother 52, 679-682.

Voss, A., Pfaller, M. A., Hollis, R. J., Melchers, W. J. \& Meis, J. F. (1998). Evaluation of the discriminatory power of pulsed-field gel electrophoresis and PCR fingerprinting for epidemiologic typing of Candida species. Clin Microbiol Infect 4, 82-87.

Wickes, B., Staudinger, J., Magee, B. B., Kwon-Chung, K. J., Magee, P. T. \& Scherer, S. (1991). Physical and genetic mapping of Candida albicans: several genes previously assigned to chromosome 1 map to chromosome R, the rDNA-containing linkage group. Infect Immun $\mathbf{5 9}$, $2480-2484$

Yang, Y. L., Cheng, H. H., Ho, Y. A., Hsiao, C. F. \& Lo, H. J. (2003). Fluconazole resistance rate of Candida species from different regions and hospital types in Taiwan. J Microbiol Immunol Infect 36, 187-191.

Yang, Y. L., Ho, Y. A., Cheng, H. H., Ho, M. \& Lo, H. J. (2004). Susceptibilities of Candida species to amphotericin B and fluconazole: the emergence of fluconazole resistance in Candida tropicalis. Infect Control Hosp Epidemiol 25, 60-64. 